\title{
Do Firms Benefit From Corporate Alleviation? From the Perspective of Signaling Theory and Information Asymmetry
}

\author{
Tan Shirong ${ }^{1, *}$ \\ ${ }^{1}$ School of International economic and trade, Shandong University of Finance \& Economics, Jinan, Shandong \\ 210046, China \\ *Corresponding author. Email: T1098069441@163.com
}

\begin{abstract}
Precision is a national strategy for poverty alleviation, is a key step for a country towards achieving common prosperity and socialist modernization, in which not only is the work of the government and the masses, enterprises should also undertake the social responsibility. On the one hand, enterprises participate in the precision for poverty alleviation work to provide funds for poverty alleviation, and provide a way out of poverty for the masses. On the other hand, enterprises can also promote their positive image and obtain government resources through poverty alleviation. Therefore, this paper analyzes the sample data of non-financial listed companies participating in targeted poverty alleviation in the stock market from 2016 to 2020, and discusses the impact of enterprises' participation in poverty alleviation on company stock price fluctuations. The results show that: (1) the participation of enterprises in poverty alleviation will increase the fluctuation of stock price. (2) The participation of enterprises in poverty alleviation will reduce the prediction error of analysts. (3) Information disclosure by enterprises will increase the prediction error of analysts. Research proves that enterprises involved in poverty reduction to the enterprise itself to influence cannot be determined, so the enterprise should combine their own actual situation to decide whether to participate in poverty alleviation, but involved in poverty reduction can reduce analysts forecast error, is helpful for investors to make the right investment decisions, but should be alert to the enterprise of incomplete information disclosure make the analysts' forecast error to the growths.
\end{abstract}

Keywords: corporate poverty alleviation, information disclosure, stock price fluctuation, analyst forecast error.

\section{INTRODUCTION}

Since the last century, our country put forward the concept of poverty alleviation, has experienced more than 30 years of hard work and made brilliant achievements, among them, the precision of poverty alleviation is the improved system for poverty alleviation in our country in view of the extensive existing problems, whose principle is "the clear bottom, heavy hematopoietic, efficiency"[16]. In order to realize the precise poverty reduction, in addition to the national government, enterprises are also participated. On October 17, 2015, the national federation of industry and commerce, poverty relief office of the State Council and China's glorious officially launched "thousands of enterprises help thousands of villages", and put forward the "federation of industry and commerce system organization private enterprises to carry out the" thousands of companies to help thousands of village "precise poverty relief action", "enterprise + poor" as the main train of thought, combining with local resources and advantage of enterprise, to provide money and technology to local, help local agriculture, tourism, manufacturing and other industries, create the enterprise accurate model for poverty alleviation, greatly improve the efficiency of poverty alleviation. Since then, companies all over the country to set up the social image, get government support and so on a variety of reasons have been engaged in poverty alleviation in the boom, according to the blue book for poverty alleviation for enterprises (2020), according to data released More than $90 \%$ of China's top 100 enterprises actively participate in poverty alleviation, 61 enterprises disclosed the amount of poverty alleviation investment 
in 2019, a total of 6.82 billion yuan, the average investment of each enterprise $111,807,700$ yuan, $32.61 \%$ higher than in 2018, while the enterprise has successfully improved its social reputation and obtained political resources, It can be seen that poverty alleviation occupies part of the resources of normal business activities of enterprises, which will have an impact on enterprises.

The traditional view is that, from the perspective of shareholder interest maximization, the behavior of the enterprises to participate in poverty alleviation and enterprise run counter to the interests of the creative activities, and with the resource dependence theory and social exchange theory and the development of stakeholder theory, only satisfy shareholders and ignore the rights and interests of other stakeholders including consumers, the local government, Local residents are no longer enough to support the long-term development of the company. [3]Taking corporate social responsibility plays a positive role in establishing a good corporate image, maintaining social network relations and reducing transaction costs. So far, researchers have found that enterprises to actively participate in poverty alleviation and information disclosure to improve corporate performance, reduce the cost of equity financing, reduce business risk,[6] [16]but for the influence of the company's share price, has always had different conclusions, some scholars think that enterprises participate in poverty alleviation acted as a management company cover the negative information from tools, so there is the risk that they might crash, at the same time, With the increasing transparency of corporate information, when a company fails to meet investors' requirements for information disclosure, its stock price will fall. However, some scholars believe that enterprises' participation in poverty alleviation increases the transparency of financial reports, thus helping to mitigate the risk of stock price collapse. At the same time, there is still no research on the long-term impact of corporate poverty alleviation on enterprises several years later. Therefore, this paper takes Shanghai and Shenzhen A-share listed companies from 2016 to 2020 as samples and conducts A systematic study on the long-term impact of corporate poverty alleviation on company stock price fluctuations according to the stakeholder theory.

The possible contributions of this paper are as follows: (1) from the perspective of stock price fluctuations, this paper explores the impact of enterprises' participation in poverty alleviation on themselves. (2) It makes up for the lack of research on the influence of poverty alleviation on the long-term fluctuations of the stock prices of enterprises in the future. (3) The relationship between the participation in poverty alleviation and the information transparency of enterprises and the forecast error of analysts is analyzed.
The structure of the remainder is as follows: The second part is theoretical analysis and research hypothesis; The third part is the research design; The fourth part is the results and analysis; The fifth part is the robustness test; The sixth part is the conclusion and revelation

\section{THEORETICAL ANALYSIS AND RESEARCH HYPOTHESIS}

\section{1. participation in poverty alleviation and stock price fluctuation}

The resource dependence theory shows that enterprises need to obtain resources in the environment to maintain their survival. No organization is selfsustaining and must exchange with the environment. The participation of enterprises in poverty alleviation is an effective way to exchange social resources[2]. The exchange of production factors between enterprises, the government and the poor households, that is, the government provides convenient policy funds and resources, and the poor households provide land and labor, can effectively reduce the operating costs of enterprises and improve the operating performance. [1012]At the same time, targeted poverty alleviation and poverty alleviation is an important measure for the Party and the country to build a moderately prosperous society in an all-round way and realize the great rejuvenation of the Chinese nation, which is the focus of policy at the present stage. Under this political background, the participation of enterprises in poverty alleviation can win public favor, improve social reputation, establish corporate image and bring longterm market value. [7][15]All these pro-business factors will be reflected in the stock market according to the efficient market hypothesis. But businesses to participate in poverty alleviation will occupy the resources of the enterprise, may lead to increased risk of business problems such as shortage of funds that, at the same time, increasing uncertainty once involved in poverty alleviation project cannot be completed or enterprise in which the negative news, pocketing enterprises through this project, for example, can make the enterprise loss of public trust, reflected in the stock market, stock prices fluctuations. On the other hand, according to the behavioral finance, corporate action reflects the enterprise's operating conditions, so companies involved in precise poverty alleviation can deliver the enterprise financial situation is good, have great potential for development of related signal allows investors to trust the company stock, to attract investors to invest for the long term, is advantageous to the enterprise stable operation, share price volatility drops, [18]so the assumptions are: 
H1a: The participation of enterprises in targeted poverty alleviation will increase the fluctuation of stock price.

H1b: The participation of enterprises in targeted poverty alleviation will reduce the volatility of stock prices.

\section{2. corporate information disclosure and stock price fluctuation}

In the stock market in the process of information transmission, the information transparency of listed companies determines the efficiency of information transfer and resource allocation efficiency, the stronger the information transparency, can guide the capital flow to the profit ability, high growth of enterprises, to strengthen the resource utilization efficiency, on the other hand, would hinder efficient resource allocation, degree of transparency of information affects the enterprise decision makers to make the right decision, Investors make efficient investment decisions and regulators can achieve effective regulation, and according to the stakeholder theory, all of these decide the company's operating performance, however, information between enterprises, investors and regulators tend to be unequal, asymmetric information theory is to point to in the market economy activities, all kinds of staff there are differences between the understanding of the relevant information is; Those with sufficient information are often in a favorable position, while those with poor information are in a disadvantageous position. In the enterprise, the enterprise management personnel belongs to the party that holds more sufficient information, on the one hand, enterprises to participate in precision for poverty alleviation, the reputation of social responsibility formed when insurance can take negative effect in enterprise have the effect of buffer, the social responsibility information disclosure can be passed to the market a lot of non financial information, has the information communication effect, [4]improve the enterprise information transparency, Reduce investors expected returns evaluation parameter uncertainty, the enterprise is more popular with investors, by raising the stock price, on the other hand, the enterprise internal personnel for self-interest purpose concealing the negative information, to conceal the public disclosure only positive information enterprise, when negative information hoarding to lead to share price decline, [8] in addition, It is also a difficult problem for a company to provide investors with the information they need without disclosing its confidential information. [9] When the information disclosed by the company fails to meet the needs of investors, the company will lose the trust of investors and have a negative impact on the stock price. Therefore, whether the stock price rises or falls, corporate information transparency is positively correlated with stock price volatility. But on the other hand, more detailed financial reporting and more transparent information disclosure to the market to provide more accurate information about the enterprise characteristic, help investors future analysis enterprise may encounter the situations (e.g., cash flow), when these real happen in the future, the market reaction will be more dull, share price volatility is abate, at the same time, the noise is less capital markets, Company's quality information has a leading role to influence the stock price, more transparent information disclosure relieves the enterprise internal management and external investors and the degree of information asymmetry between outside investors, reduce the investors trading behavior are affected by the noise outside, resulting in a decline in stock price volatility and calculated the enterprise information transparency and stock price volatility is negative correlation. [14]Therefore, the impact of increased information disclosure degree of enterprises through participating in poverty alleviation on stock price volatility is uncertain. We assume that:

$\mathrm{H} 2 \mathrm{a}$ : The higher the level of information disclosure of enterprises participating in targeted poverty alleviation, the greater the fluctuation of stock price.

$\mathrm{H} 2 \mathrm{~b}$ : The higher the level of information disclosure of enterprises involved in targeted poverty alleviation, the smaller the fluctuation of stock price.

\section{3. corporate information disclosure and analyst forecast error}

Traditional disclosure of accounting information as the center of gravity, the lack of attention to the nonfinancial information, the lack of forward-looking, unable to face risks and opportunities to the company to conduct a comprehensive analysis, so in recent years, with the subject of environment and social responsibility information of non-financial information gradually to the attention of the regulators, companies and investors, especially since 2006. The Shenzhen Stock Exchange issued the Guidelines on Social Responsibility for Listed Companies, advocating listed companies to undertake social responsibility and voluntarily disclose corporate social responsibility reports. These regulations have led companies to report more and more social responsibility information each year, providing a wealth of material for analysts to do non-financial analysis. [5]However, due to the lack of effective external supervision, some companies selectively report social responsibility information, which makes it impossible for analysts to conduct objective analysis of the company's earnings, and is easy to mislead analysts to make overly optimistic analysis. At the same time, the researchers showed that analysts can through information model and reputation in a certain extent affect the direction of the market, analysts, especially star analyst, by publishing research reports affect 
investors' decision-making, and analysts for the enterprise to make overly optimistic evaluation can make analysts report lose credibility, to reduce the enterprise information opacity no benefit, On the contrary, the more optimistic the analyst is, the greater the risk will be considered by investors and the stock price will fall. Therefore, it is assumed that:

H3: The higher the level of information disclosure of enterprises involved in targeted poverty alleviation, the greater the profit forecast error of analysts will be.

\subsection{The poverty alleviation of enterprise and the forecast error of the analysts}

Since 2016, China has stipulated that enterprises should disclose social responsibility information and issue social responsibility reports. The situation of enterprises participating in poverty alleviation will be reflected in the corporate social responsibility reports. According to the signal theory, enterprises participating in poverty Alleviation will release more internal information about enterprises to the outside world through the social responsibility report, so that analysts can have more information to predict and analyze the company's stock price, thus improving the accuracy of analysts' profit error. However, at the same time, the participation of enterprises in poverty alleviation generally sends a signal to the market that the enterprises are in good financial condition, which makes analysts make overly optimistic predictions about the stock prices of enterprises, thus increasing the prediction error of analysts. Therefore, for the impact of enterprises' participation in poverty alleviation on analysts' forecast errors, [13][17]we assume that:

H4: Enterprises' participation in targeted poverty alleviation will increase the profit forecast error of analysts.

\section{STUDY DESIGN}

\subsection{Data processing}

This paper selects all a-share listed companies in China from 2016 to 2020 as research samples. The original samples are treated as follows: (1) Considering the particularity of financial and insurance industry companies' accounting statements, this type of companies is excluded; (2) In order to avoid the interference of abnormal financial indicators caused by the company's poor operation, samples treated by ST and ST in the year of poverty alleviation were eliminated by referring to luo Dang Theory et al. (2016); (3) Eliminate the missing data of targeted poverty alleviation. ; (4) Excluding the samples with missing key financial data, a total of 818 enterprises and 1688 companies' annual observed values were obtained; (5) In order to eliminate the influence of outliers, all continuous variables in this paper are processed with Winsorize of up and down 1\%. Targeted poverty alleviation data of enterprises are from CSMAR data. Finally, 10,159 enterprise samples were obtained, and the data were all from CSMAR database.

\subsection{Variable definition and measurement}

Independent variables. (1) Participates in poverty alleviation or not: The enterprises shown on the poverty alleviation work sheet in the CSR report indicate that they participate in poverty alleviation, while the enterprises not shown in the table mean that they do not participate in poverty alleviation. If they do, the value is 1 , and if they do not, the value is 0 . (2) Corporate information disclosure: In this paper, according to whether there is a follow-up poverty alleviation plan variable in the poverty alleviation statistical table in the CORPORATE social responsibility report, 1 is yes, and 0 is no.

Dependent variables. (1) Price change it is defined as the standard deviation of stock return rate in the current year. Specifically, it is calculated as: the standard deviation of monthly closing price of various stocks in each year is calculated. (2) analyst earnings forecast: This paper refers to existing literature related to analyst earnings forecast and designs the following model to verify the hypothesis of this paper:

FERRORt $+1=\alpha 0+\alpha 1$ ASSURANCEt $+\alpha 2$ NUMt + $\alpha 3$ TRANSPt $+\alpha 4$ UEt $+\alpha 5$ SHR $1 \mathrm{t}+\alpha 6$ MGNSHRt $+\alpha 7$ SIZEt $+\alpha 8$ STATEt $+\sum$ IND $+\sum$ YEAR + epsilon zero (1)

In the model, the explained variable FERROR is the error of analysts' earnings forecasts for companies that disclose social responsibility reports. The smaller the value, the smaller the deviation of analysts' earnings forecasts. The specific calculation formula is as follows:

FERROR = ACTUALEPS-mean (FORECASTEDEPS) /PRICE (3)

Where, ACTUALEPS represents actual earnings per share, FORECASTEDEPS represents analyst forecast earnings per share, and PRICE represents the opening PRICE for the year. Bondt and Thaler found that the larger the time span of analysts' earnings forecasts, the greater the forecast error.[1] Therefore, this paper distinguishes analysts' earnings forecasts in different years and sets the maximum forecast time span as two years.[17]

Control Variables. Based on the existing literature, a series of other factors that may affect the risk of stock price collapse of enterprises are controlled from the aspects of enterprise management, corporate governance and stock market performance. In terms of enterprise operation, market return (Meps), asset-liability ratio 
(Daratio), return on Total assets (ROA) and market-to-

book ratio $(\mathrm{BM})$ are controlled.

Table 1 Definition of major variables

\begin{tabular}{|c|c|c|c|}
\hline Variable types & $\begin{array}{l}\text { Variable } \\
\text { name }\end{array}$ & $\begin{array}{l}\text { Variable } \\
\text { meaning }\end{array}$ & Variable definition \\
\hline \multirow[t]{2}{*}{ Dependent variable } & stdClsdt & $\begin{array}{l}\text { Price } \\
\text { fluctuation }\end{array}$ & The standard deviation of that year's closing price \\
\hline & FERROR & $\begin{array}{l}\text { The error of } \\
\text { analysts' } \\
\text { earnings } \\
\text { forecasts }\end{array}$ & $\begin{array}{l}\text { [The average of all analysts' last earnings forecasts } \\
\text { for a company before its annual report - the } \\
\text { company's actual earnings) } \div \text { the stock price at the } \\
\text { beginning of the year } \times 100\end{array}$ \\
\hline \multirow[t]{2}{*}{ Independent variable } & pov & $\begin{array}{l}\text { Whether the } \\
\text { enterprise } \\
\text { alleviates } \\
\text { poverty }\end{array}$ & $\begin{array}{l}\text { Dummy variable, participating in poverty alleviation } \\
\text { takes } 1 \text { and not participating in poverty alleviation } \\
\text { takes } 0\end{array}$ \\
\hline & disclosure & $\begin{array}{l}\text { Enterprise } \\
\text { information } \\
\text { disclosure }\end{array}$ & $\begin{array}{l}\text { The dummy variable, whether the enterprise has } \\
\text { the follow-up poverty alleviation work, is } 1 \text {, not } 0\end{array}$ \\
\hline \multirow[t]{4}{*}{ Control variable } & Meps & $\begin{array}{l}\text { Market } \\
\text { gains }\end{array}$ & $\begin{array}{l}\text { The average weekly specific return of stock I in } \\
\text { year T times } 100\end{array}$ \\
\hline & LEVi & $\begin{array}{l}\text { Financial } \\
\text { leverage }\end{array}$ & The asset-liability ratio of t stock I in year $\mathrm{T}$ \\
\hline & daratio & $\begin{array}{l}\text { Return on } \\
\text { total assets }\end{array}$ & $\begin{array}{l}\text { The return on total assets of stock I in year T times } \\
100\end{array}$ \\
\hline & BM & $\begin{array}{l}\text { Market to } \\
\text { book ratio }\end{array}$ & The book-to-market ratio of stock $\mathrm{T}$ I in year $\mathrm{T}$ \\
\hline
\end{tabular}

\section{RESULTS}

\subsection{Descriptive analysis}

Table 2 lists the descriptive results of all variables. In the sample, the mean standard deviation of the closing price in the same year and month is 1.75 , the standard deviation is 0.95 , the minimum value is 0.5 , and the maximum value is 13.02 . It can be seen that the sample data vary greatly. In the sample companies, the average error of analysts' earnings forecast is -3.12 , and the standard deviation is 9.71 , indicating that different analysts' earnings forecast results for Uni-President enterprises are quite different. The average value of the variable whether enterprises participate in poverty alleviation is 0.4 , indicating that $40 \%$ of enterprises participate in poverty alleviation. The average value of enterprise information disclosure variable is 0.88 , indicating that $88 \%$ of enterprises have made information disclosure. The descriptive statistical results of other variables are basically consistent with the existing literature and will not be repeated.

Table 2 Descriptive analysis

\begin{tabular}{lcccc}
\hline variable & mean & sd & $\min$ & $\max$ \\
stdClsdt & 1.750 & 0.950 & 0.500 & 13.02 \\
\hline ferror & -3.120 & 9.710 & -298.1 & 92.31 \\
disclosure & 0.880 & 0.320 & 0 & 1 \\
pov & 0.400 & 0.490 & 0 & 1 \\
Meps & 0.570 & 1.200 & -16.46 & 37.17 \\
daratio & 0.440 & 0.210 & 0.0100 & 3.650 \\
ROA & 0.0400 & 0.180 & -14.30 & 1.410 \\
BM & 1.500 & 2.640 & 0.0300 & 35.35 \\
\hline
\end{tabular}




\subsection{Correlation analysis}

Table 3 shows the statistical results of the correlation of sample data. It can be seen that the correlation coefficient between stock price fluctuation and whether enterprises participate in poverty alleviation is positive but not significant at the $10 \%$ significance level, and the correlation coefficient between stock price fluctuation and enterprise information disclosure variable is also positive but not significant. The correlation coefficient between analysts' earnings forecast error and whether enterprises participate in poverty alleviation is positive but not significant, and the correlation coefficient between analysts' earnings forecast error and enterprise information disclosure is positive and significant. This result can preliminarily verify that there is no significant relationship between the volatility of the company's stock price and whether the company participates in poverty alleviation or not and whether the company discloses its information, while there is a positive correlation between the analyst's earnings forecast error and whether the company participates in poverty alleviation or not and whether the company discloses its information, which can be further verified through regression analysis.

Table 3 Correlation analysis

\begin{tabular}{|c|c|c|c|c|c|c|c|c|}
\hline stdClsdt & $\begin{array}{c}\text { stdClsdt } \\
1\end{array}$ & ferror & disclo e & pov & Meps & daratio & ROA & $\overline{B M}$ \\
\hline ferror & $-0.0422^{*}$ & 1 & & & & & & \\
\hline disclosur & -0.0159 & $0.0406^{\star}$ & 1 & & & & & \\
\hline pov & 0.0125 & 0.00520 & . & 1 & & & & \\
\hline Meps & $-0.0594^{*}$ & $0.4231^{*}$ & $0.0424^{*}$ & $0.0303^{*}$ & 1 & & & \\
\hline daratio & $0.0642^{*}$ & $-0.2739^{*}$ & $0.1066^{*}$ & $0.2170^{*}$ & $-0.1525^{*}$ & 1 & & \\
\hline ROA & $-0.0387^{*}$ & $0.4712^{*}$ & -0.00590 & -0.0158 & $0.3755^{\star}$ & $-0.2163^{*}$ & 1 & \\
\hline BM & 0.0146 & $-0.1213^{*}$ & $0.0998^{*}$ & $0.2087^{*}$ & -0.00960 & $0.5239^{*}$ & $-0.0650^{*}$ & 1 \\
\hline
\end{tabular}

Note: $* * *, * * *$ mean significant at the level of $10 \%, 5 \%$ and $1 \%$ respectively.

\subsection{Regression analysis}

Table 4 shows the regression results of hypothesis $\mathrm{H} 3$ and $\mathrm{H} 4$ in this paper. Column 1 shows the results of the independent variables whether enterprises participate in poverty alleviation and enterprise information disclosure are not included. In Column 2, the variable whether enterprises participate in poverty alleviation is included, and the correlation is 0.121 $(\mathrm{t}=0.049)$, which is significantly positive at the level of $5 \%$. It is verified that THE participation of $\mathrm{H} 1 \mathrm{a}$ enterprises in targeted poverty alleviation will increase the fluctuation of stock price. The variable of enterprise information disclosure is added in Column 3 , and the correlation coefficient is $-0.052(\mathrm{t}=0.044)$, which is not significant, indicating that $\mathrm{H} 2$ is not valid. As for the analyst forecast error of the dependent variable in columns 4 to 6 , we add the variable whether enterprises participate in poverty alleviation in column 5 , and the result shows that the correlation coefficient is -0.994 , which is significantly negative at the $10 \%$ level, indicating that enterprises participate in poverty alleviation to reduce the analyst forecast error. In Column 6, enterprise information disclosure is introduced. The correlation coefficient is $0.939(\mathrm{t}=0.369)$, which is significantly positive at the $5 \%$ level, verifying the hypothesis of $\mathrm{H} 4$ that information disclosure by enterprises will increase the analysis error of analysts.

Table 4 Regression analysis

\begin{tabular}{lcccccc}
\hline & M1 & M2 & M3 & M4 & M5 & M6 \\
\hline Meps_w & -0.046 & -0.047 & 0.033 & $2.825^{* * *}$ & $2.835^{* * * *}$ & $1.462^{* * *}$ \\
& $(0.046)$ & $(0.046)$ & $(0.024)$ & $(0.371)$ & $(0.371)$ & $(0.362)$ \\
& & & & & & \\
daratio_w & 0.370 & 0.354 & 0.007 & $-5.253^{* * *}$ & $-5.140^{* * *}$ & $4.783^{* * *}$ \\
& $(0.260)$ & $(0.261)$ & $(0.088)$ & $(1.290)$ & $(1.290)$ & $(0.799)$ \\
& & & & & & \\
ROA_w & 0.377 & 0.388 & $-0.757^{*}$ & $47.440^{* * *}$ & $47.276^{* * *}$ & $53.236^{* * *}$ \\
& $(0.434)$ & $(0.434)$ & $(0.411)$ & $(3.013)$ & $(3.015)$ & $(4.368)$
\end{tabular}




\begin{tabular}{|c|c|c|c|c|c|c|}
\hline \multirow[t]{2}{*}{ BM_w } & $0.047^{* *}$ & $0.048^{* *}$ & -0.004 & $-0.992^{* * *}$ & $-0.965^{* * *}$ & $-0.234^{* * *}$ \\
\hline & $(0.021)$ & $(0.021)$ & $(0.004)$ & $(0.167)$ & $(0.165)$ & $(0.071)$ \\
\hline \multirow[t]{2}{*}{ pov_w } & & $0.121^{* *}$ & & & $-0.994^{* * *}$ & \\
\hline & & $(0.049)$ & & & $(0.164)$ & \\
\hline \multirow[t]{2}{*}{ disclosure_w } & & & -0.052 & & & $0.939^{* *}$ \\
\hline & & & $(0.044)$ & & & $(0.369)$ \\
\hline \multirow[t]{2}{*}{ _cons } & $1.507^{* * *}$ & $1.471^{* * *}$ & $1.808^{* * *}$ & $-2.696^{* * *}$ & $-2.460^{* * *}$ & $-8.438^{* * t+}$ \\
\hline & $(0.118)$ & $(0.119)$ & $(0.057)$ & $(0.640)$ & $(0.636)$ & $(0.538)$ \\
\hline$N$ & 7659 & 7659 & 2641 & 8980 & 8980 & 2920 \\
\hline$R^{2}$ & 0.002 & 0.003 & & 0.567 & 0.569 & \\
\hline $\operatorname{adj} . R^{2}$ & 0.002 & 0.003 & & 0.567 & 0.569 & \\
\hline
\end{tabular}

Standard errors in parentheses

$* \mathrm{P}<0.10, * * \mathrm{P}<0.05, * * * \mathrm{P}<0.01$

M1-m3: the dependent variable is standard deviation

M4-m6: The dependent variable is analyst forecast error

\section{Conclusion and Enlightenment}

This paper takes Shanghai and Shenzhen A-share listed companies from 2016 to 2020 as samples to test the impact of corporate participation in poverty alleviation and corporate information disclosure on stock price fluctuations and analyst forecast errors. The research finds that (1) the participation of enterprises in poverty alleviation will increase the fluctuation of stock price. (2) The participation of enterprises in poverty alleviation will reduce the prediction error of analysts. (3) Information disclosure by enterprises will increase the prediction error of analysts.

From the perspective of stock price fluctuation, this paper puts forward the economic impact of enterprises' participation in poverty alleviation, which provides references for enterprises and investors. The increased stock price fluctuation shows that the impact of enterprises' participation in poverty alleviation on enterprises is uncertain, which may not only bring reputation effect to enterprises and increase the stock price, but also cause enterprises to consume resources and increase their operational risks. Therefore, enterprises should make decisions based on their own reality and environmental factors. However, the positive correlation between participation in poverty alleviation and stock price fluctuations can help investors to predict and make preparations in advance when they make investments. On the other hand, this paper analyzes the impact of enterprises' participation in poverty alleviation and disclosure from the perspective of analysts' forecast errors. This paper verifies that enterprises can publish social responsibility reports through poverty alleviation to enable analysts to obtain more information and make more accurate predictions. And enterprise information disclosure for enterprises to carry out selective report or makes a overly optimistic forecast of analysts to reinforce analysts' forecast error, so investors should not completely trust analysts in investment, be alert analyst will be based on the enterprise a overly optimistic forecast of incomplete report, analysts also should be vigilant, to judge the authenticity of the enterprise's report. At the same time, the government, industry organizations and regulatory authorities should strengthen supervision over enterprises' participation in poverty alleviation, improve relevant laws and regulations, standardize and guide enterprises to provide true, complete and reliable financial reports, such as disclosing more non-financial information, and improve the operation efficiency and norms of the capital market.

\section{References}

[1] Bondt W D, Thaler R H. Do security analysts overreact? [J] . American Economic Review, $1990,80(2): 52-57$. 
[2] Deng Bofu, Tao Cunjie, Ji Li. Enterprises' Participation in targeted Poverty alleviation and alleviating financing constraints [J].Journal of finance and economics,2020,46(12):138-151.

[3] Zhang Xiuping. The Impact of participating in targeted Poverty alleviation on enterprise performance [J]. Reform,2020(08):117-131.

[4] Huang Jinbo, Chen Lingqian, DING Jie. Corporate social responsibility, media reports and stock price crash risk [J/OL]. China management science: 1-12 [2021-07-29].

[5] Li Zheng, Li Zengquan. Whether there is Information content in corporate Social Responsibility report verification Opinion -Empirical Evidence from Listed Companies in China [J]. Audit Research, 2012(1) : 78-86.

[6] Liu Bai, Lu Jiarui. "Following the Trend" or "opportunistic" : Research on the contagion mechanism of corporate social responsibility [J]. Nankai management review,2018,21(04):182-194.

[7] Quan Xiaofeng, WU Shinong, Yin Hong-ying. Corporate Social Responsibility and the Risk of Stock Price Crash [J]. Economic research journal,2015,50(11):49-64.

[8] Quan Xiaofeng, XU Xingmei, Xu Rong. Management opportunism under mandatory disclosure of Social responsibility: Empirical evidence based on A-share listed companies [J]. Journal of management science,2018,21(12):95110 .

[9] Song xianzhong, $\mathrm{Hu}$ Jun, Li Sihai. Social responsibility information disclosure and stock price crash risk: a path analysis based on information effect and reputation insurance effect [J]. Financial Research,2017(04):161-175.

[10] Tao Chunhua, Yang Sijing, Lin Wanfa. Corporate governance, corporate social responsibility and stock price crash risk [J]. Journal of xiangtan university (philosophy and social sciences edition), 2015,39(06):50-56.

[11] Wang Fan, Tao Yuan-ting, Ni Juan. Research on the investment efficiency and performance of listed companies under the background of targeted poverty alleviation -- Based on the sample of private enterprises

[12] Wang Yaping, Liu Huilong, Wu Liansheng. Information transparency, investment institutions and share prices[J]. Financial Research,2009.

[13] Wang Siyu, Chen Weiqing. Research on the relationship between corporate poverty alleviation and financial performance: Based on the moderating effect of ownership concentration [J]. Financial And Accounting Bulletin,2021(10):44$46+65$.

[14] Xie Huobao, Shi Jia, Hui Lili. Strategic differences, information transparency and earnings forecast quality of financial Analysts: Empirical evidence from Shenzhen Listed companies [J]. Journal of nanjing audit university,2018,15(04):28-35.

[15] Xin Qingquan,Kong Dongmin,He Ying.Corporate transparency and stock price volatility[J].Financial Research,2014,\{4\}(10):193-206.

[16] Yang Guocheng,Wang Zhimin.Can private enterprises' participation in poverty alleviation curb the risk of stock price collapse[J].Journal of Guangdong University of Finance and Economics,2021,36(02):86-101.

[17] Zhang Yuming, Xing Chao. Analysis on the effect and mechanism of enterprises' participation in industrial targeted poverty alleviation -- Empirical evidence from China's A-share market[J]. Business Research,2019(05):109-120.

[18] Zhang Zhengyong, Hu Yanyan, Ji Li. Can corporate social responsibility report verification reduce analyst earnings forecast bias? [J]. Journal of audit and economics,2017,32(05):85-95. [J]. China Soft Science, 2020(6) : 122-135.

[19] Zhen Hongxin, Wang Sanfa. Does targeted poverty alleviation affect enterprise risk? [J]. Financial Research,2021(01):131-149. 